\title{
A DISPARIDADE RECURSAL NO JULGAMENTO ANTECIPADO PARCIAL DE MÉRITO E O PRINCÍPIO DA ISONOMIA
}

\author{
THE DISPARITY OF APPEAL IN THE EARLY PARTIAL JUDGMENT OF MERIT AND THE \\ PRINCIPLE OF ISONOMY
}

\section{Thiago Caversan Antunes}

\begin{abstract}
Doutor em Direito pela Universidade de Marília (UNIMAR), mestre em Direito Negocial e especialista em Direito Civil e Processo Civil pela Universidade Estadual de Londrina (UEL). É professor da Faculdade Positivo de Londrina e de diversos cursos de pós-graduação lato sensu. É membro da Associação Brasileira de Direito Processual (ABDPro) e da Associação Brasileira de Direito e Economia (ABDE). Atua como advogado. E-mail: thiago@caversan.adv.br
\end{abstract}

\section{Rogerio Mollica}

Doutor e Mestre em Direito Processual Civil pela USP. Especialista em Administração de Empresas CEAGFundação Getúlio Vargas- SP. Especialista em Direito Tributário pelo Instituto Brasileiro de Estudos Tributários IBET. Bacharel em Direito pela USP. Professor Doutor nos Cursos de Mestrado e Doutorado na Universidade de Marilia - Unimar. Advogado. Membro fundador e ex-Presidente do Ceapro - Centro de Estudos Avançados de Processo. Membro do Instituto Brasileiro de Direito Processual (IBDP). Membro do Instituto Brasileiro de Direito Tributário (IBDT).

E-mail: rogerio@caisadvogados.com.br

Recebido em:09/12/2020 Aprovado em: 22/04/2021

RESUMO: O estudo que ora se apresenta tem como objetivo analisar as diferenças de tratamento infraconstitucional das sistemáticas recursal e de efetivação de sentenças de mérito e decisões interlocutórias que veiculam julgamento antecipado parcial de mérito. Utiliza como método de pesquisa a análise dedutiva e toma como sistema de referência a hermenêutica crítica. Parte de uma investigação do princípio da isonomia, segundo o regramento constitucional vigente, especialmente no que interessa à dinâmica processual civil. Em seguida, traça linhas gerais sobre a sistemática recursal civil aplicável contra sentenças de mérito, assim como sobre as suas possibilidades de efetivação. Adiante, estabelece um quadro geral da sistemática recursal e de efetivação de decisões interlocutórias que veiculam julgamento antecipado parcial de mérito. Ao final, trata da aplicação da isonomia procedimental aos principais pontos de divergência entre os sistemas anteriormente delineados. Conclui que a estrita observância do texto constitucional como ápice de um ordenamento jurídico hierarquicamente escalonado determina que o recurso de agravo de instrumento interposto contra decisão interlocutória que veicula julgamento antecipado de mérito seja processado por meio de um procedimento semelhante àquele próprio ao recurso de apelação interposto contra sentença de mérito.

Palavras-chave: Agravo de Instrumento. Isonomia Processual. Julgamento Antecipado. 
ABSTRACT: The present study aims to analyze the differences in the infraconstitutional treatment of the appeal systems and the enforcement of judgments on merits and interlocutory decisions that convey partial early judgment of merits. It uses deductive analysis as a research method and takes critical hermeneutics as a reference system. It starts with an investigation of the principle of isonomy, according to the constitutional rules in force, especially with regard to civil procedural dynamics. Then, it outlines general guidelines on the civil appeal system applicable against judgments of merit, as well as on its possibilities of effectiveness. Ahead, it establishes a general framework of the appeal system and the effectiveness of interlocutory decisions that convey a partial early judgment on the merits. Finally, it deals with the application of procedural isonomy to the main points of divergence between the systems previously outlined. It concludes that the strict observance of the constitutional text as the culmination of a hierarchically scaled legal order determines that the appeal of an interlocutory appeal against an interlocutory decision that carries out an early judgment on the merits is processed through a procedure similar to that proper to the appeal filed against merit judgment.

Keywords: Intrumental Appeal. Procedural Isonomy. Early Judgment.

SUMÁRIO: Introdução. 1 O Princípio da Isonomia Aplicado ao Processo. 2 O Sistema Recursal Civil Aplicável a Sentenças de Mérito. 3 O Sistema Recursal Civil Aplicável a Decisões que Veiculam Julgamento Antecipado Parcial de Mérito. 4 Sobre a Aplicação do Princípio da Isonomia à Questão. Conclusão. Referências.

\section{INTRODUÇÃO}

O estudo que ora se apresenta tem o escopo específico de analisar as disparidades entre o sistema recursal previsto, em caráter abstrato, no Código de Processo Civil brasileiro de 2015, para impugnar sentenças de mérito, de um lado, e decisões que veiculam julgamento antecipado parcial de mérito, de outro, tudo considerado a partir da perspectiva da aplicação do princípio da isonomia à dinâmica procedimental civil.

Para tanto, utiliza-se o método dedutivo, lançando mão, como ferramenta de pesquisa, especialmente do levantamento bibliográfico e da análise contextualizada de textos normativos que dizem respeito à temática, tendo como sistema de referência a hermenêutica crítica em um cenário de ordenamento hierarquicamente escalonado que tem como ápice a Constituição Federal.

Parte-se, de início, de uma breve análise do princípio da isonomia aplicado ao processo para, em seguida, passar ao exame das distinções de tratamento procedimental subsequente à prolação de sentenças de mérito e de decisões que veiculam o julgamento antecipado parcial de mérito, especialmente na hipótese de interposição de recursos e inclusive em relação à eventual possibilidade de efetivação da respectiva decisão.

Pretende-se, ao final, demonstrar que o texto normativo infraconstitucional ora vigente ofende a garantia constitucional de tratamento isonômico, e exige especial atenção dos operadores do Direito, para que se resgate o respeito à estrutura hierarquicamente escalonada do ordenamento jurídico vigente, por meio da aplicação concreta dos procedimentos em estrita conformidade com a Constituição Federal. 


\section{O PRINCÍPIO DA ISONOMIA APLICADO AO PROCESSO}

A ideia de tratamento isonômico é tão basilar na estruturação do Estado Democrático de Direito brasileiro, ${ }^{1}$ que logo no início do rol das garantias fundamentais, mais especificamente no caput do art. $5^{\circ}$ da Constituição Federal, ${ }^{2}$ há uma tripla alusão à igualdade - quando o referido dispositivo legal estabelece que "todos são iguais perante a lei", acrescenta a observação de que isto se dá "sem distinção de qualquer natureza" e arremata que é garantida aos brasileiros e estrangeiros residentes no País, dentre outras, a inviolabilidade do direito à "igualdade". 3

É válido ressaltar, desde o início, que o texto normativo não tem - e nem poderia ter - a pretensão de inviabilizar ou anular absolutamente eventuais distinções que as pessoas possam ter entre si; o que não se admite, em princípio, é que situações idênticas recebam, pelas vias institucionais, tratamentos díspares, e nem tampouco que as desigualdades perniciosas sejam eternizadas.

Vale, neste particular, a lição de Mello (2010, p. 21):

[...] o reconhecimento das diferenciações que não podem ser feitas sem quebra da isonomia se divide em três questões: a) a primeira diz com o elemento tomado como fator de desigualação; b) a segunda reporta-se à correlação lógica abstrata existente entre o fato erigido em critério de discrimen e a disparidade estabelecida no tratamento jurídico diversificado; c) a terceira atina à consonância desta correlação lógica com os interesses absorvidos no sistema constitucional e destarte juridicizados.

Assim, também, Paula (2013, p. 99) sintetiza que

[...] não se pode adotar um critério diferenciador por si só como referencial a generalizar como discriminatório e, portanto, ofensivo à isonomia. É necessário somar a este critério justificativa razoável e adequação ao sistema normativo constitucional. Não encontrando o fecho deste triplo mecanismo, corre-se o risco de se estar diante de uma norma que ofende a isonomia.

Desta forma, é bem verdade que, em determinadas situações, o ordenamento jurídico, em caráter abstrato, e o próprio aplicador da norma, em caráter concreto, precisará tratar desigualmente os desiguais, na medida de suas desigualdades, a fim de alcançar a isonomia em seu sentido material; mas também é verdade que, afora as situações em que tal tratamento díspar encontrar fundamento específico no próprio texto constitucional, estar-se-á muito provavelmente diante de uma ofensa às garantias fundamentais ligadas à própria noção de igualdade. ${ }^{4}$

\footnotetext{
${ }^{1}$ Segundo recorda Silva (2000, p. 214), “[...] a igualdade constitui o signo fundamental da democracia". Neste mesmo sentido, Bonavides (2004, p. 376) ressalta que "o centro medular do Estado social e de todos os direitos de sua ordem jurídica é indubitavelmente o princípio da igualdade. Com efeito, materializa ele a liberdade da herança clássica. Com esta compõe um eixo ao redor do qual gira toda a concepção estrutural do Estado democrático contemporâneo".

${ }^{2}$ Vale mencionar que, antes mesmo, no preâmbulo da Constituição Federal, a igualdade já é expressamente distinguida como um dos "valores supremos" do Estado Democrático por ela instituído.

${ }^{3}$ É de se observar, também, que logo a seguir, em seu primeiro inciso, o art. $5^{\circ}$, da Constituição Federal, retoma o tema ao determinar que "homens e mulheres são iguais em direitos e obrigações, nos termos desta Constituição".

${ }^{4}$ Neste sentido, Nery Junior (2010, p. 99) pontua: "Dar tratamento isonômico às partes significa tratar igualmente os iguais e desigualmente os desiguais, na exata medida de suas desigualdades. Por isso é que são constitucionais dispositivos legais discriminadores, quando desigualam corretamente os desiguais, dando-lhes tratamentos distintos; e são inconstitucionais os dispositivos legais discriminadores, quando desigualam incorretamente os iguais, dando-lhes tratamentos distintos. Deve buscar-se na norma ou no texto legal a razão da discriminação: se justa, o dispositivo é constitucional; se injusta, é inconstitucional".
} 
Assim é que, de um lado, evidentemente, ao magistrado não é dado aplicar as normas procedimentais de maneira díspar, ${ }^{5}$ para além dos limites previstos no próprio ordenamento jurídico positivado, sob pena de ofensa não apenas à garantia fundamental de respeito ao devido processo legal, encartada no art. $5^{\circ}$, LIV, da Constituição Federal, mas, também, antes, de ofensa às já mencionadas garantias ligadas à noção de igualdade, a partir do preâmbulo do texto constitucional. ${ }^{6}$

Na dinâmica processual, a atenção, por parte do magistrado, ao dever de atenção aos limites procedimentais de tratamento das partes ganha especial relevância quando se leva em conta, também, a garantia do juiz natural, na perspectiva da imparcialidade. ${ }^{7}$

É bem neste sentido, aliás, que o Código de Ética da Magistratura Nacional prevê, no art. $8^{\circ}$, que:

O magistrado imparcial é aquele que busca nas provas a verdade dos fatos, com objetividade e fundamento, mantendo ao longo de todo o processo uma distância equivalente das partes, e evita todo o tipo de comportamento que possa refletir favoritismo, predisposição ou preconceito.

Em complemento, prevê o art. $9^{\circ}$, caput, do próprio Código de Ética da Magistratura Nacional, que, "ao magistrado, no desempenho de sua atividade, cumpre dispensar às partes igualdade de tratamento, vedada qualquer espécie de injustificada discriminação", ressalvando, contudo, no parágrafo único, inciso II, que não se considera tratamento discriminatório injustificado aquele "diferenciado resultante de lei".

Neste contexto, ganha relevância a noção de que o próprio ordenamento jurídico infraconstitucional não deve, em princípio, ainda que de forma genuinamente abstrata, criar hipóteses de tratamento diferenciado para partes que futuramente se encontrem em situação de equivalência de condições, sob pena de ofensa às diversas garantias ligadas ao conceito de igualdade, e ainda pelo risco de redução concreta dos próprios limites práticos da imparcialidade.

É bem neste sentido que Silva (2000, p. 221) observa que,

A concepção de que o princípio da igualdade perante a lei se dirige primariamente ao legislador avulta a importância da igualdade jurisdicional. Pois, se o princípio se dirigisse apenas ao aplicador da lei, bastaria a este respeitar o princípio da legalidade e o da igualdade estaria também salvo. No sentido da concepção exposta, que é a correta e pacificamente aceita, o princípio da igualdade consubstancia uma limitação ao legislador, que, sendo violada, importa na inconstitucionalidade da lei [...]. Constitui, por outro lado, uma regra de interpretação para o juiz, que deverá sempre dar à lei o entendimento que não crie distinções. $^{8}$

\footnotetext{
${ }^{5}$ Segundo observa Medina (2017, p. 45), "rege-se o processo pelo princípio constitucional da isonomia (art. $5^{\circ}$, caput e I, da CF), devendo o juiz assegurar às partes igualdade de tratamento (art. 139, I, do CPC/2015)".

${ }^{6}$ Aqui, vale recordar a lição de Bonavides (2007, p. 139 e 140): "A sobrevivência da democracia liga-se ao êxito que eventualmente possa alcançar uma teoria política que afirme e reconcilie a idéia dos direitos sociais, que faz lícita uma maior intervenção do poder estatal na esfera econômica e cultural, com a idéia não menos justa do individualismo, que pede a segurança e o reconhecimento de certos direitos fundamentais da personalidade, sem os quais esta se deformaria e definharia, como fonte que se deve sempre conservar de iniciativas úteis, livres e fecundas".

${ }^{7}$ Nery Junior (2010, p. 130) leciona: "A garantia do juiz natural é tridimensional. Significa que: 1) não haverá juízo ou tribunal ad hoc, isto é, tribunal de exceção; 2) todos têm o direito de se submeter a julgamento (civil ou penal) por juiz competente, pré-constituído na forma da lei; 3 ) o juiz competente tem de ser imparcial".

${ }^{8}$ Assim, também, Oliveira Neto e Oliveira (2008, p. 143) asseveram que, "sendo a isonomia um dos princípios constitucionais que dá base a todo o sistema jurídico, salta aos olhos que este valor deve estar inserto em todas as normas de natureza processual, sob pena da inconstitucionalidade da norma".
} 
A garantia fundamental da isonomia aplicada ao processo, assim, exige não apenas que, concretamente, os magistrados atuem na função jurisdicional de maneira imparcial, na forma determinada pelo Código de Ética da Magistratura Nacional, sob as luzes do texto constitucional, mas também que o próprio legislador, em abstrato, não estabeleça, de antemão, no nível infraconstitucional tratamento diferenciado a partes que se encontrem em situações processuais equivalentes.

\section{O SISTEMA RECURSAL CIVIL APLICÁVEL A SENTENÇAS DE MÉRITO}

Traçado um breve panorama geral sobre o princípio da isonomia aplicado ao processo, exclusivamente naquilo que interessa ao enfrentamento do tema objeto deste resumido estudo, cabe passar a uma breve análise da dinâmica recursal aplicável, segundo o Código de Processo Civil de 2015, às sentenças de mérito, bem como sobre seus principais reflexos em relação à respectiva sistemática de efetivação.

Vale, assim, recordar que o art. 203, $\S 1^{\circ}$, do Código de Processo Civil vigente, define sentença como "[...] o pronunciamento por meio do qual o juiz, com fundamento nos arts. 485 e 487, põe fim à fase cognitiva do procedimento comum, bem como extingue a execução".

Importam, para os estreitos limites do estudo que ora se apresenta, apenas as sentenças de mérito, isto é, aquelas que, em princípio, põem fim à fase cognitiva do procedimento comum, no primeiro grau de jurisdição, com fundamento no art. 487, do Código de Processo Civil - o que ocorre, mais especificamente, quando o juiz acolhe ou rejeita o pedido formulado na ação ou na reconvenção; decide sobre a ocorrência de decadência ou prescrição; ou homologa o reconhecimento de procedência do pedido da parte contrária, a transação ou, ainda, a renúncia à pretensão formulada pela parte adversa no litígio.

Contra tais pronunciamentos jurisdicionais, segundo a previsão do art. 1.009, caput, do Código de Processo Civil, cabe a interposição do recurso de apelação, ${ }^{9}$ que, como regra geral, por força da previsão do art. 1.012, caput, daquele mesmo diploma legal, tem efeito suspensivo legal - ressalvadas as hipóteses excepcionais elencadas nos incisos do $\S 1^{\circ}$, do próprio art. 1.012, em que a atribuição de efeito suspensivo da eficácia da sentença recorrida, por parte do relator, dependerá de o apelante "demonstrar a probabilidade de provimento do recurso ou se, sendo relevante a fundamentação, houver risco de dano grave ou de difícil reparação", segundo o que dispõe o $\S 4^{\circ}$, daquele mesmo art. 1.012, do Código de Processo Civil.

Uma das principais consequências práticas da aplicação de tal dinâmica recursal é o fato de que, por força da redação do art. 520, caput, do Código de Processo Civil, na pendência do julgamento de recurso de apelação, como regra geral, é juridicamente inviável que a parte que figura como credora no título executivo judicial até então existente, ou seja, na própria sentença, pleiteie o início da fase de cumprimento provisório de sentença.

Isto ocorre porque o caput do art. 520, do Código de Processo Civil, prevê, apenas, o cabimento de cumprimento provisório de sentença impugnada por recurso desprovido de efeito suspensivo, enquanto, como já visto, o art. 1.012, caput, do próprio Código de Processo Civil, determina que o recurso de apelação, como regra geral, terá efeito suspensivo da eficácia da decisão recorrida.

Tal conjuntura normativa pode soar bastante exótica, mormente quando levado em conta que o recurso cabível contra uma série de decisões interlocutórias, proferidas com base em um exercício de cognição sumária, é o agravo de instrumento, regulado pelos art. 1.015 e seguintes, do Código de Processo Civil, que não tem efeito suspensivo legal da eficácia da decisão recorrida, e

\footnotetext{
${ }^{9}$ Cabe ressalvar que, contra a sentença, em particular, assim como contra os pronunciamentos jurisdicionais em geral, também cabe a oposição de embargos de declaração, nas hipóteses do art. 1.022, do Código de Processo Civil, quando a pretensão for de "correção de vícios" e não exatamente de "reforma ou decretação de nulidade".
} 
que, assim, poderá ser objeto de efetivação imediata, por força do que consta do art. 297, parágrafo único, e do art. 520, caput, do Código de Processo Civil.

Além do mais, vale destacar que nos recursos de apelação, em geral, é viável a realização de sustentação oral, pelas partes - o que somente seria cabível, em relação aos agravos de instrumento, nos recursos que versem sobre as tutelas provisórias de urgência ou da evidência, tudo conforme as disposições do art. 937, I e VIII, do Código de Processo Civil.

Também é de se mencionar que, segundo a previsão do art. $997, \S \S 1^{\circ}$ e $2^{\circ}$, II, do Código de Processo Civil, a interposição de recurso de apelação por uma das partes em litígio dá à parte contrária a possibilidade de interposição de recuso adesivo ${ }^{10}$ - inexistindo, contudo, previsão legal específica de cabimento da medida no agravo de instrumento.

Há, ainda, um ponto que merece atenção, no art. 1.013, $\S \S 3^{\circ}$ e $4^{\circ}$, do Código de Processo Civil, que consagra, especificamente em relação ao recurso de apelação, a chamada "teoria da causa madura" - e que não encontra equivalente no capítulo que trata do recurso de agravo de instrumento, o que terá desdobramentos relevantes no que diz respeito ao recurso interposto contra a decisão que veicula julgamento antecipado parcial de mérito, conforme se verá adiante.

\section{O SISTEMA RECURSAL CIVIL APLICÁVEL A DECISÕES QUE VEICULAM DE JULGAMENTO ANTECIPADO PARCIAL DE MÉRITO}

Delineadas (ainda que com atenção limitada ao estrito objeto do estudo que ora se apresenta) as características gerais do sistema recursal previsto no Código de Processo Civil de 2015 aplicável às sentenças civis de mérito, assim como os seus principais reflexos nas possibilidades de efetivação, cabe passar a uma breve investigação da sistemática aplicável às decisões que veiculam julgamento antecipado parcial de mérito.

Vale lembrar que, segundo o art. 356, do Código de Processo Civil, cabe ${ }^{11}$ o julgamento antecipado parcial do mérito quando um ou mais dos pedidos formulados, ou parcela deles, for tido no processo como incontroverso, ou estiver em condições de imediato julgamento pela

\footnotetext{
${ }^{10}$ É de se destacar que, segundo o art. 997, § 2º II, do Código de Processo Civil, é admissível, também, o recurso adesivo no recurso extraordinário e no recurso especial.

${ }^{11} \mathrm{Na}$ realidade, vale anotar que a redação do caput do art. 356, do Código de Processo Civil de 2015, sugere "dever" e não simplesmente "faculdade" do magistrado de proceder ao julgamento antecipado parcial de mérito, sempre que viável, o que pode ser visto como consequência da garantia fundamental de "razoável duração do processo", encartada no art. $5^{\circ}$, LXXVIII, da Constituição Federal, e repisada também no art. $4^{\circ}$, do próprio Código de Processo Civil em vigor. Neste mesmo sentido, Theodoro Júnior (2017a, p. 850) assevera que "na sistemática de nosso atual sistema processual civil, o julgamento antecipado e parcial do mérito não é visto como faculdade, mas, sim, como um dever do juiz, segundo o tom imperativo do art. 356, nas duas situações nele enumeradas, 'o juiz decidirá parcialmente o mérito', ordena o dispositivo legal. Trata-se de uma exigência do princípio que impõe a rápida e efetiva solução da lide, requisito fundamental à configuração do princípio que impõe a rápida e efetiva solução da lide, requisito fundamental à configuração da garantia constitucional do processo justo (moderna visão do devido processo legal)". Assim, também, Lucon (2015, p. 591), ao tratar do julgamento antecipado parcial de mérito, afirma: "Trata-se de medida destinada a viabilizar um processo adequado, que atende à promessa constitucional de um processo célere $(\mathrm{CF}$, art. $5^{\circ}$, LXXVIII). Gerir bem o processo significa atender às especificidades da relação jurídica de direito material e ao que já se encontra demonstrado nos autos". Da mesma maneira, Marinoni, Arenhart e Mitidiero (2017a, p. 158): "Como o direito de ação tem de promover uma tutela jurisdicional tempestiva, então é evidente que o processo deve consumir apenas o tempo estritamente necessário para viabilizar o adequado conhecimento da causa e a pertinente execução do julgado (arts. $5^{\circ}$, LXXVIII, da CF, e $4^{\circ}$ ). Por vezes, o processo alberga um litígio que pode ser fracionado ou então pedidos formulados em regime de cumulação simples que podem ser decididos autonomamente. Nesses casos, representaria certamente uma má gestão do tempo do processo deixar de decidir parte incontroversa da demanda ou um dos seus pedidos que se afigure incontroverso apenas para que se tenha a oportunidade de decidir o litígio como um todo ao mesmo tempo. Se a parte tem direito à tutela tempestiva, certamente constitui violação a esse direito fazêla aguardar o desfecho de seu pedido - ou de parcela dele - para além do tempo necessário para maturação do julgamento". Para Carnevali (2016, p. 386), também, “[...] desde que observado o contraditório, impõe-se o julgamento no instante em que a parcela do litígio não mais requer atividade probatória para ser solucionada. Para esta parcela, o processo torna-se inútil e incompatível com o princípio da razoável duração".
} 
desnecessidade de produção de outras provas que não aquelas que já se encontrem incorporadas aos autos. ${ }^{12} 13$

Segundo explica Theodoro Júnior (2017a, p. 850):

Os casos que ensejam o julgamento parcial de mérito, de acordo com o art. 356, são dois:

a) quando, entre os diversos pedidos cumulados, um ou mais deles, ou parcela deles "mostrar-se incontroverso"; ou

b) "estiver em condições de imediato julgamento", segundo a regra do art. 355 . Ou seja:

i) quando, para solução de parte destacável do objeto litigioso, não houver necessidade de produção de "outras provas", além daquelas disponíveis nos autos (caso em que, por exemplo, a questão a dirimir for apenas de direito, ou sendo de direito e de fato, mostrar-se solucionável mediante exame apenas dos documentos já produzidos em juízo); ou

ii) quando a revelia produzir o efeito de presunção de veracidade (art. 344) sobre parte apenas das alegações de fato formuladas pelo autor (caso em que, por exemplo, o réu revel comparece ao processo a tempo de requerer prova, e de fato requer contraprova pertinente, nos moldes do art. 349, afetando, porém, tão somente uma parcela da demanda. ${ }^{14}$

No que interessa mais diretamente a este estudo, é necessário observar que o art. 356, § $5^{\circ}$, do Código de Processo Civil, prevê que a decisão que veicula julgamento antecipado parcial de mérito será impugnável por meio de agravo de instrumento - o que, ademais, encontra-se em conformidade com a previsão do art. 1.015, II, do próprio Código de Processo Civil. ${ }^{15}$

Neste sentido, Lucon (2015, p. 592) explica que:

Decisões interlocutórias [...] podem versar sobre o mérito de uma demanda, mas elas não encerram o processo. A possibilidade de decisões interlocutórias versarem a respeito do mérito do processo é confirmada pela previsão do art. 1.015 do Código de Processo Civil, segundo o qual é cabível a interposição de agravo de instrumento contra as decisões interlocutórias que versarem sobre decisão dessa natureza. É isso o que ocorre justamente nos casos de julgamento parcial antecipado. $\mathrm{O}$ conteúdo dessa decisão inegavelmente se enquadra nas hipóteses.

\footnotetext{
${ }^{12}$ Aqui, também vale observar que, segundo o parágrafo único do art. 370, do Código de Processo Civil, cabe ao juiz, por meio de decisão fundamentada, indeferir as diligências probatórias que se revelem inúteis ou meramente protelatórias, o que evidentemente dependerá fundamentalmente das circunstâncias específicas de cada caso concreto. ${ }_{13}^{13}$ Bueno (2017, p. 451), ao tratar do julgamento antecipado parcial de mérito, explica: "Não se trata [...] de o magistrado acolher em parte o pedido do autor, concedendo 80 a quem pedira 100, por exemplo. Trata-se, bem diferentemente, de o magistrado conceder os danos emergentes pedidos porque os considera suficientemente provados e determinar que tenha início a fase instrutória para pesquisar a ocorrência de lucros cessantes".

${ }^{14} \mathrm{Na}$ síntese de Marinoni, Arenhart e Mitidiero (2017b, p. 467), "as hipóteses que autorizam a possibilidade de julgamento imediato parcial do mérito são as mesmas que viabilizam o julgamento imediato: a desnecessidade de produção de provas diversa daquela já colhida (art. 356, CPC)". Bueno (2016, p. 363) também ensina que "[...] é correto entender que as duas situações do art. 356 acabam se sobrepondo, em alguma medida, e, nesse sentido, são passíveis de serem compreendidas como aqueles casos em que um ou mais dos pedidos formulados ou parcela deles dispensam a produção de 'outras provas', a viabilizar, ao menos com relação a eles, a desnecessidade da fase instrutória e, por isto, o julgamento antecipado".

${ }^{15}$ Donizetti (2017b, p. 495), ao tratar do julgamento antecipado parcial de mérito, pondera: "Não se trata de uma antecipação dos efeitos de eventual sentença de mérito, função destinada à antecipação de tutela. A decisão é, em seu conteúdo, parte da sentença, sendo, pois, capaz de impedir nova apreciação do julgador. Em síntese, é decisão que se submete aos limites objetivos da futura coisa julgada. No entanto, sendo decisão que não extingue o processo ou a atividade cognitiva como um todo, mas apenas parte da demanda, ela não deve ser objeto de recurso de apelação. Nesse sentido, sob a perspectiva da técnica processual, a decisão ainda é interlocutória, desafiando o recurso de agravo de instrumento".
} 
Tal decisão, contudo, não é apta a extinguir a fase cognitiva do procedimento comum que terá prosseguimento para julgamento da parcela do mérito não resolvida. Em atenção a isso, o art. $356, \S 5^{\circ}$, estabelece como cabível o recurso de agravo de instrumento contra a decisão que julgar parcela do mérito em caráter antecedente.

Ocorre, contudo, que, diversamente do que ocorre com o recurso de apelação, que tem, como visto no tópico anterior, como regra geral, efeito suspensivo legal, por força da determinação do art. 1.012, do Código de Processo Civil, o recurso de agravo de instrumento, por falta de previsão legal específica neste sentido no capítulo que trata dessa matéria (isto é, nos art. 1.015 a 1.020, daquele mesmo diploma legal), ficaria sujeito ao regime geral do art. 995, do próprio Código de Processo Civil, segundo o qual "os recursos não impedem a eficácia da decisão recorrida, salvo disposição legal ou decisão judicial em sentido diverso", até porque o art. 1.019, I, prevê, também, mais especificamente, que a atribuição de efeito suspensivo ao agravo de instrumento depende de decisão do relator neste sentido. ${ }^{16}$

Como se não bastasse - e para que não paire dúvida a respeito da inexistência de “disposição legal”, no nível infraconstitucional, aplicável à hipótese em exame - é necessário notar que o $\S 2^{\circ}$, do art. 356, do Código de Processo Civil de 2015, prevê, em termos expressos, que "a parte poderá liquidar ou executar, desde logo, a obrigação reconhecida na decisão que julgar parcialmente o mérito, independentemente de caução, ainda que haja recurso contra essa interposto". ${ }^{17}$

Trata-se, assim, não apenas de um reforço da noção de que, nesta circunstância, não teria supostamente o recurso de agravo de instrumento um efeito suspensivo legal - dependendo, portanto, de um exame de probabilidade e de risco, por parte do relator - mas também de exceção à regra prevista no art. 520, IV, do Código de Processo Civil, para além das hipóteses elencadas nos incisos art. 521 - e com aparente afastamento da previsão constante do parágrafo único, do próprio art. 521, do Código de Processo Civil, no sentido de que, no cumprimento provisório de sentença, "a exigência de caução será mantida quando da dispensa possa resultar manifesto risco de grave dano de difícil ou incerta reparação".

Dito de outra forma, considerada isoladamente a redação do art. 356, § $2^{\circ}$, do Código de Processo Civil em vigor, aparentemente a exigência de caução para a prática de atos de expropriação ou de satisfação, no cumprimento de decisão que veicula o julgamento antecipado parcial de mérito dependeria da concessão específica de uma tutela de urgência, desde que o executado consiga convencer o magistrado, no caso concreto, da existência de probabilidade de seu direito e também do risco de dano ou de ineficácia - o que configura uma situação

\footnotetext{
${ }^{16}$ Theodoro Júnior (2017b, p. 1057), discorrendo sobre os efeitos do agravo de instrumento, leciona que "[...] o efeito suspensivo poderá, em determinados casos, ser concedido pelo relator. Dois são os requisitos da lei, a serem cumpridos cumulativamente, para a obtenção desse benefício: (i) a imediata produção de efeitos da decisão recorrida deverá gerar risco de dano grave, de difícil ou impossível reparação; e (ii) a demonstração da probabilidade de provimento do recurso (arts. 995, parágrafo único, e 1.010, I)”.

${ }^{17}$ Neste sentido, Câmara (2017, p. 219), ao tratar do tema, afirma que "caso interposto o agravo de instrumento, será possível promover desde logo a liquidação (se necessária) ou a execução da obrigação reconhecida na decisão de julgamento parcial de mérito, independentemente de caução (art. $356, \S \S 1^{\circ}$ e $2^{\circ}$ ), salvo se atribuído efeito suspensivo ao agravo de instrumento (art. 1.019, I), caso em que a decisão interlocutória não produzirá desde logo seus efeitos". Assim também Marinoni, Arenhart e Mitidiero (2017b, p. 467) sugerem que "há possibilidade de execução imediata da decisão que julga parte do mérito, tendo em conta que o recurso de agravo de instrumento não tem efeito suspensivo (arts. 356, § $2^{\circ}$, e 520, CPC)". Da mesma forma, Montenegro Filho $(2015$, p. 57) afirma que, "considerando que o processo tem continuidade após o seu julgamento parcial, para ser posteriormente encerrado por sentença, a decisão proferida com base na norma em exame é de natureza interlocutória, podendo ser atacada pelo recurso de agravo de instrumento, no prazo de 15 dias úteis, permitindo que o recorrente solicite a atribuição do efeito suspensivo ao remédio processual, com fundamento no inciso I do art. 1.019".
} 
sensivelmente diversa daquela aplicável nos casos de cumprimento de sentença, como se viu no tópico anterior deste mesmo estudo.

Vale registro o entendimento consolidado no Enunciado 49, firmado no Seminário "O Poder Judiciário e o Novo Código de Processo Civil", da Escola Nacional de Formação e Aperfeiçoamento de Magistrados (ENFAM), segundo o qual "no julgamento antecipado parcial de mérito, o cumprimento provisório da decisão inicia-se independentemente de caução (art. 356, § $2^{\circ}$, do CPC/2015), sendo aplicável, todavia, a regra do art. 520, IV”.

De acordo com o aludido enunciado, portanto, o $\S 2^{\circ}$, do art. 356, do Código de Processo Civil em vigor dispensaria caução, apenas, para o início da execução da decisão que veicula julgamento antecipado parcial de mérito, mas não para "o levantamento de depósito em dinheiro e a prática de atos que importem transferência de posse ou alienação de propriedade ou de outro direito real, ou dos quais possa resultar grave dano ao executado".

A leitura sugerida pelo enunciado, conquanto interessante, aparentemente não tem fundamento na legislação infraconstitucional, haja vista que a legislação processual absolutamente não exige prestação de caução para início de execução de qualquer espécie ${ }^{18}$ - e vale lembrar que não se está diante de decisão que veicule espécie de "tutela provisória".

Assim, Bueno (2017, p. 451) assevera que

$\mathrm{O} \S 2^{\circ}$ do art. 356 , de qualquer sorte, permite que, nesse caso, o cumprimento provisório - não só o início da fase propriamente dita, mas, mais do que isso, a satisfação do direito perseguido nela - dê-se independentemente de caução, previsão que, nesse sentido, excepciona a regra genérica do inciso IV do art. 520.

Neste mesmo sentido, Theodoro Júnior (2017a, p. 851) leciona:

Pelas circunstâncias especiais em que ocorre o julgamento antecipado parcial do mérito (ou seja, na ausência de controvérsia entre as partes e com existência de prova suficiente do direito que fundamenta a causa), o art. $356, \S 2^{\circ}$, dispensa o credor de prestar caução para a promoção imediata do cumprimento provisório do julgado. Isto, porém, não exime o exequente provisório do dever de repor o executado no estado anterior à execução, caso seu recurso seja afinal provido [...].

Ainda, vale observar que, segundo o art. 937, VIII, no recurso de agravo de instrumento, seria supostamente cabível a sustentação oral apenas quando "interposto contra decisões interlocutórias que versem sobre tutelas provisórias de urgência ou da evidência". 19

Também é de se observar que o art. 942, § $3^{\circ}$, II, do Código de Processo Civil, prevê a ampliação do colegiado de julgadores, em caso de divergência na apreciação de agravo de instrumento, apenas quando houver reforma da decisão que julgar parcialmente o mérito - não estendendo a possibilidade, assim, aos casos em que houver divergência, mas prevalecer o entendimento de manutenção da decisão recorrida.

Além do mais, conforme já adiantado na parte final do tópico anterior deste mesmo estudo, a legislação infraconstitucional vigente também não faz previsão específica do cabimento de

\footnotetext{
${ }^{18}$ Neste sentido, Bueno (2016, p. 364), também afirma que "não tem sentido entender que o $\S 2^{\circ}$ do art. 356 limita-se a permitir o início da fase de cumprimento provisório ou de liquidação independentemente de caução porque tal possibilidade é de todo o sistema, não havendo espaço para supor que o CPC de 2015 tenha querido, no particular - e justamente no ponto que pretende inovar substancial e expressamente - regredir na disciplina que vem sendo dada ao tema da execução provisória desde as reformas ocorridas no CPC de 1973 na década de 2000".

${ }^{19}$ Theodoro Júnior (2017b, p. 1063), discorrendo sobre o julgamento do agravo de instrumento pelo colegiado, reafirma: "O NCPC (art. 937) enumera os casos de cabimento da sustentação oral, dentre os quais está o agravo de instrumento contra decisões interlocutórias sobre tutelas provisórias de urgência ou da evidência (inciso VIII). Portanto, não são todos os agravos de instrumento que admitem a sustentação oral".
} 
recurso de agravo de instrumento na forma adesiva, nem tampouco da possibilidade de aplicação da chamada "teoria da causa madura".

\section{SOBRE A APLICAÇÃO DO PRINCÍPIO DA ISONOMIA À QUESTÃO}

Conforme demonstrado nos dois tópicos imediatamente anteriores deste breve estudo, o Código de Processo Civil de 2015 estabelece tratamento profundamente diverso à sistemática recursal e às possibilidades de efetivação de sentenças de mérito e de decisões que veiculam julgamento antecipado parcial de mérito, não obstante ambas sejam proferidas como resultado de um exercício de cognição exauriente, ${ }^{20}{ }^{21}$ o que configura, em princípio, ofensa às garantias constitucionais ligadas à igualdade. ${ }^{22}$

Vale, neste ponto, recordar a lição de Neves (2015, p. 226), ao tratar do art. 356, do Código de Processo Civil:

$\mathrm{O} \S 2 .^{\circ}$ do dispositivo ora comentado é interessante porque libera a liquidação ou execução imediata na obrigação reconhecida na decisão que julgar parcialmente o mérito, independentemente de caução, ainda que haja recurso pendente de julgamento. O dispositivo é compatível com o $§ 5 .^{\circ}$ que prevê a

decisão ser recorrível por agravo de instrumento, recurso sem efeito suspensivo. Há, entretanto, uma gritante contradição entre qualquer decisão que resolva o mérito e seja recorrível por apelação e a decisão que julga antecipadamente parcela do mérito. Enquanto no primeiro caso será inviável, ao menos em regra, a execução em razão do efeito suspensivo do recurso, no segundo será

cabível a execução provisória. A distinção de tratamento não tem qualquer justificativa lógica ou jurídica plausível, porque trata julgamentos de mérito de

\footnotetext{
${ }^{20}$ Lucon (2015, p. 590) afirma, categoricamente, que "o julgamento antecipado [...] apenas tem lugar se proferido com base em cognição exauriente. Nada o difere do julgamento emanado após a fase instrutória, a não ser o momento em que foi proferido". Assim também, Marinoni, Arenhart e Mitidiero (2017a, p. 159) lecionam: "O que foi decidido mediante julgamento antecipado parcial é decidido com base em cognição exauriente e não pode o juiz voltar a examiná-lo no decorrer do processo". Neste mesmo sentido, Araújo (2017, p. 93): "O novel diploma processual deixa clara a possibilidade de, no curso da relação processual, ocorrer decisão com caráter definitivo parcial [...] estando sujeita ao recurso de agravo de instrumento. Neste caso, o agravo tem a mesma função da apelação e, se não for interposto, poderá gerar a formação da coisa julgada parcial em relação ao capítulo de mérito resolvido na forma do art. 356, do CPC/15". Da mesma forma, Didier (2017, p. 773): “O julgamento antecipado é uma decisão de mérito, fundada em cognição exauriente [...]”.

${ }^{21}$ Donizetti (2017a, p. 511), discorrendo sobre a decisão que veicula julgamento antecipado parcial de mérito, afirma: "Nesse caso, a decisão tem feição de sentença, porém, como não põe fim ao processo ou a alguma de suas fases, será impugnável por agravo de instrumento (art. $356, \S 5^{\circ}$ ). Em outras palavras, é como se no processo existissem duas 'sentenças', sendo a primeira referente à parte incontroversa, impugnável por agravo de instrumento, e a segunda referente ao mérito como um todo, que seguirá a regra da impugnação por meio de apelação. Vale ressaltar que mesmo existindo duas (ou até mais) 'sentenças', a decisão que julga antecipada e parcialmente o mérito não dependerá de ulterior confirmação: ela já é definitiva e pode resultar em coisa julgada material antes mesmo de o processo ser extinto".

${ }^{22}$ Carnevali (2016, p. 395) sugere que "[...] a opção do legislador, em conferir natureza de decisão interlocutória àquela que julga apenas parcela da demanda, parece não alinhar-se com o princípio da isonomia, especialmente no âmbito recursal. Ora, aquela decisão será definitiva, autossuficiente. Não precisará ser ratificada e também não poderá ser modificada por meio de sentença, apenas podendo ser revista pela instância superior com o manejo do agravo de instrumento, cujo procedimento diferencia-se da apelação em inúmeros aspectos (arts. 1.009 e ss.; e arts. 1.015 e ss. do NCPC)". Adiante, o autor repisa: "Ora, fere o princípio da isonomia sustentar que decisões de conteúdo idêntico tenham tratamento distinto quanto aos efeitos dos recursos delas cabíveis, simplesmente porque proferida no curso ou no final do processo. Se decisão interlocutória fosse, seria impugnável por meio de agravo, que não conta com inúmeras garantias estabelecidas na apelação, recurso que permite às partes maior oportunidade de debater a causa e ao judiciário de analisá-la em segundo grau de jurisdição" (CARNEVALI, 2016, p. 399). Neste mesmo sentido, Araújo (2019, p. 89) assevera que "[...] devem ser aplicadas ao agravo de instrumento contra resolução parcial de mérito as mesmas garantias do recurso de apelação, inclusive pela necessidade de tratamento igualitário das partes no processo".
}

Revista de Direito Brasileira | Florianópolis, SC | v. 28 | n. 11 | p.334-350 | Jan./Abr. 2021 
maneira distinta quanto à sua eficácia imediata sem nada que justifique o tratamento desigual, em nítida ofensa ao princípio da isonomia. Sou um crítico do efeito suspensivo como regra na apelação, mas, uma vez sendo essa a opção legislativa, realmente fica complicado compreender por que a decisão que julga antecipadamente parcela do mérito pode ser executada provisoriamente.

Por outro lado, a previsão expressa do $\S 5 .^{\circ}$ de que a decisão que julga antecipadamente parcela do mérito é recorrível por agravo de instrumento gera problemas porque teremos no sistema processual dois recursos distintos ao segundo grau para reexame de decisão de mérito.

É necessário, portanto, que se procure estabelecer parâmetros claros para que a aplicação dos mecanismos previstos na legislação infraconstitucional, sem ignorar as orientações que emanam do texto normativo, coadune-se com as determinações da própria Constituição Federal, mormente quando consubstanciadas em garantias fundamentais.

É bem verdade, por um lado, que, considerada a própria previsão encartada no art. $5^{\circ}$, LXXVIII, da Constituição Federal, de razoável duração do processo, poder-se-ia, por exemplo, ter a tentação de cogitar a extinção do efeito suspensivo legal ao recurso de apelação, como regra geral, a partir da via da interpretação - mas, aparentemente, essa é uma solução inviabilizada pelo inciso LIV, do próprio art. $5^{\circ}$, da Constituição Federal, que estabelece como requisito de legitimidade ao exercício do poder institucionalmente organizado contra a liberdade ou os bens das pessoas físicas e jurídicas, em geral, a estrita observância do "devido processo legal". 23

Assim, aparentemente, a compatibilização do tratamento infraconstitucional destinado às sentenças de mérito e às decisões que veiculam julgamento antecipado de mérito com o princípio da isonomia precisa, necessariamente, ocorrer por meio do exercício interpretativo mais benéfico à parte que se encontre, ainda que abstratamente, na posição de ver sua própria liberdade ou seu patrimônio sujeitos subsequentemente à atuação do Poder Judiciário, especialmente por meio das tutelas jurisdicionais de caráter executivo. ${ }^{24}$

Desta forma, considerando-se, a um só tempo, a necessidade de tratamento isonômico de litigantes que, ainda que em caráter abstrato, estejam em condições de paridade, e também o imperativo de respeito ao devido processo legal, parece possível afirmar que, não obstante a previsão da primeira parte do caput do art. 995, do Código de Processo Civil de 2015, de que "os recursos não impedem a eficácia da decisão", e também da redação do art. 1.019, I, daquele mesmo diploma legal, no sentido de que a atribuição de efeito suspensivo a agravo de instrumento depende de decisão do relator neste sentido, os agravos de instrumento interpostos contra decisões judiciais que veiculem julgamento antecipado parcial de mérito, na forma do art. $356, \S 5^{\circ}$, daquele mesmo

\footnotetext{
${ }^{23}$ Aqui, vale a advertência de Delfino (2020, p. 56 e 57): “Tem-se hoje verdadeiro fetiche pela celeridade, como se fosse verdadeiro que, para o constituinte, o processo adequado significasse processo rápido. Trata-se de visão distorcida. A Constituição ora alguma faz menção à celeridade processual; refere-se, isto sim, à duração razoável, algo a demonstrar que a garantia fundamental à duração razoável não implica comando normativo a obrigar julgamentos, sempre e inadvertidamente, breves. Nada mais óbvio, aliás. Afinal, julgamento sem dilações indevidas não pode se traduzir em ausência de segurança ou falta de qualidade na prestação jurisdicional. Trocando em miúdos: a aplicação desse comando constitucional jamais deve desconsiderar outras garantias de idêntico calibre, sob pena de se preponderar o arbítrio de uma prestação jurisdicional que, embora ligeira, se apresentará divorciada de fundamentos normativos constitucionais que efetivamente também regulam e legitimam o curso da atividade jurisdicional".

${ }^{24}$ Neste sentido, já se sinalizou: "Se, de um lado, as pessoas têm como garantia fundamental de liberdade a certeza de que não terão sua liberdade ou patrimônio cerceados pelo poder público sem estrita observância do procedimento previsto no próprio ordenamento jurídico, o Poder Judiciário, por outro lado, tem o respeito ao devido processo legal como método de trabalho legítimo. Dito de outra maneira, as formalidades estabelecidas na legislação como parte integrante do devido processo legal constituem limite à atuação não arbitrária e não totalitária dos magistrados de todos os graus de jurisdição" (ANTUNES, 2020, p. 279 e 280).
}

Revista de Direito Brasileira | Florianópolis, SC | v. 28 | n. 11 | p.334-350 | Jan./Abr. 2021 
diploma legal, serão dotados, como regra geral, de efeito suspensivo "natural", na forma do art. 1.012, caput, do próprio Código de Processo Civil. ${ }^{25}$

Vale ressaltar que não se pretende advogar, aqui, a ideia de que a atribuição de efeito suspensivo legal, como regra geral, a recursos interpostos contra sentenças ou decisões de mérito, seja uma consequência natural e inescapável da previsão constitucional de respeito ao devido processo legal - mas, sim, que apenas o legislador infraconstitucional pode determinar as situações em que o efeito suspensivo da eficácia da decisão recorrida será excepcional, em circunstâncias que não ofendam a determinação de tratamento isonômico, em caráter abstrato. ${ }^{26}$

Além disto, também é importante observar que, exatamente por se tratar de situações de fundo genuinamente análogas - recursos interpostos contra decisões de primeiro grau de mérito, proferidas com base em cognição exauriente - é necessário que, não obstante a aparente limitação do art. 997, § $2^{\circ}$, II, do Código de Processo Civil, seja admitida a possibilidade de interposição de recurso de agravo de instrumento adesivo, quando interposto contra decisão interlocutória que veicula julgamento antecipado parcial de mérito.

É necessário observar, também, que, precisamente por se estar diante de situações jurídicas que, afinal, mostram-se equivalentes, não se pode negar aos advogados das partes, no agravo de instrumento interposto contra decisão interlocutória que veicula julgamento antecipado parcial de mérito, ${ }^{27}$ a possibilidade de sustentação oral, segundo a sistemática do art. 937, do Código de Processo Civil ${ }^{28}$ - e isto não obstante a aparente limitação do inciso VIII, daquele mesmo artigo.

Bem neste sentido, o Enunciado 61, aprovado na I Jornada de Direito Processual Civil, do Conselho da Justiça Federal, afirma que "deve ser franqueado às partes sustentar oralmente as suas razões, na forma e pelo prazo previsto no art. 937, caput, do CPC, no agravo de instrumento que impugne decisão de resolução parcial de mérito (art. $356, \S 5^{\circ}$, do CPC)".

Também neste sentido, Medina (2015, p. 835) explica:

Deve-se admitir sustentação oral, também, em agravo de instrumento interposto contra decisão interlocutória de mérito (cf. art. 1.015, II, do CPC/2015). No caso, não se admite apelação apenas por não se tratar de decisão final [...], mas isso não altera a substância da decisão recorrida, que, sendo de mérito, tem aptidão para fazer coisa julgada $\left[\ldots . .{ }^{29}\right.$

\footnotetext{
${ }^{25}$ Neste sentido, o Enunciado 13, do Centro de Estudos Avançados de Processo (CEAPRO), sugere que "o efeito suspensivo automático do recurso de apelação, aplica-se ao agravo de instrumento interposto contra a decisão parcial do mérito prevista no art. 356 (artigo 1.015)".

${ }^{26}$ Neste mesmo sentido, Medeiros Neto (2020): “[...] não necessariamente defende que o sistema processual ideal é aquele que prevê que a sentença de mérito deva ser recorrida através de recurso de apelação que tenha o efeito suspensivo automático. Mas, defende sim, com todas as letras, que se o legislador optou por conferir efeito suspensivo automático para o recurso de apelação, não existe razão cientifica para retirar a previsão de efeito suspensivo automático para o agravo de instrumento a ser manejado contra a decisão parcial de mérito do artigo 356 do CPC/15, que nada mais representa do que uma verdadeira sentença parcial antecipada de mérito. E nessa linha, de coerência sistêmica, as hipóteses excepcionais previstas no próprio artigo 1012 do CPC/15, nas quais a apelação deve ser recebida apenas com efeito devolutivo, também se aplicariam, em tese, ao agravo de instrumento interposto contra a decisão parcial de mérito do artigo 356 do CPC/15".

${ }^{27}$ Medina (2015, p. 377 e 378) salienta que "é correto afirmar, no regime do CPC/2015, que a decisão que julga parte dos pedidos (decisão parcial), embora diga respeito ao mérito, não é sentença. Sentença, no regime do CPC/2015 (e de modo diferente, portanto, do previsto no CPC/1973), é apenas a decisão que põe fim ao processo, no sentido do $\S$ $1^{\circ}$ do art. 203 do CPC/2015. Não é correto, também, afirmar-se que no caso há 'sentença parcial', embora seja possível falar em decisão parcial (em oposição à decisão global, que será sempre sentença'”.

${ }^{28}$ Donizetti (2017a, p. 1224) assevera que "a sustentação oral não é apenas um direito da parte, mas uma prerrogativa profissional do advogado que a representa".

${ }^{29}$ Da mesma maneira, Lemos (2016a, p. 11): “A decisão parcial de mérito é uma parte daquilo que o autor imaginava ser julgado na sentença, a qual, se recorrível, seria totalmente impugnável pela apelação, com total possibilidade de sustentação oral. Se o juízo deve, de acordo com o art. 356, proferir a decisão parcial - quando verificar suas hipóteses, 
Não é sem razão, portanto, que o art. 942, § $3^{\circ}$, II, do Código de Processo Civil, prevê a aplicação da técnica de ampliação de colegiado no caso de julgamento não unânime de recurso de apelação também ao agravo de instrumento, "quando houver reforma da decisão que julgar parcialmente o mérito". 30

É de se ressalvar, contudo, que, segundo as premissas a partir das quais se vem desenvolvendo este estudo, parece possível deduzir que a técnica de ampliação de colegiado deve ser aplicada, também, nos casos em que o julgamento não unânime do agravo de instrumento ocorrer no sentido de manter a decisão interlocutória que veicula julgamento antecipado parcial de mérito - de maneira semelhante ao que ocorre com o recurso de apelação em situações semelhantes. $^{31}$

Adiante, quando efetivamente pendente recurso desprovido de efeito suspensivo, será viável, a critério da parte até então credora, pleitear o início de um cumprimento provisório, segundo a sistemática prevista nos art. 520 a 522, do Código de Processo Civil - observadas as peculiaridades do art. 356, $\S 4^{\circ}$, do próprio Código de Processo Civil.

Neste particular, esclarece Siqueira (2016, p. 428):

Causa certa estranheza [...] a expressão "independentemente de caução", que dá a ideia de que mesmo quando seja provisória a execução, será processada sem aquela garantia. Ocorre que [...] o art. 520, IV do CPC/15 exige, dentre os cuidados inerentes a este tipo de execução, a prestação de caução para que possam ser praticados atos expropriatórios.

Não se justifica, porém, a diferença de tratamento: seja de sentença ou de decisão interlocutória, a execução, caso qualquer dessas decisões esteja sujeita a recurso, ostentará a marca da provisoriedade. E, sendo assim, as garantias que se justificam em uma também devem existir na outra.

Por derradeiro, cumpre observar que, não obstante a chamada teoria da causa madura tenha restado positivada no art. $1.013, \S \S 3^{\circ}$ e $4^{\circ}$, em capítulo especificamente dedicado à regulamentação do procedimento de do recurso de apelação, sem equivalente no capítulo que trata do recurso de agravo de instrumento, caso se presuma a possibilidade em si como legítima, ${ }^{32} \mathrm{o}$

o recurso cabível deveria conter a mesma disponibilidade da sustentação oral, por, de igual modo, impugnar uma decisão de mérito, ainda que seja interlocutória. Uma latente omissão legislativa". No mesmo sentido, Oliveira (2017, p. 10), afirma que "[...] é incorreto não admitir sustentação oral apenas porque o julgamento (com ou sem resolução de mérito) recaiu sobre apenas um ou alguns dos pedidos formulados. Tendo havido julgamento do pedido, o direito à sustentação oral deve ser o mais amplo possível. Como regra, portanto, nos agravos que versem sobre decisão de mérito ou parcial de mérito também deve ser admitida a sustentação oral. Nesses casos, visto a evidente analogia, aplica-se o regime da apelação".

${ }^{30}$ Segundo Oliveira (2017, p. 11), “[...] qualquer apelação está sujeita ao disposto no art. 942. Porém, o texto do inc. II do $\S 3^{\circ}$ inclui no rol somente o agravo de instrumento que tenha sido provido para reformar a decisão recorrida. Foi criada, desse modo, distinção puramente casuística, não havendo razão lógica para explicar tal opção legislativa".

${ }^{31}$ Otávio Neto, Pereira e Alves (2016, p. 364), discorrendo sobre o julgamento antecipado parcial de mérito, sugerem: "Malgrado seu conteúdo de sentença, a decisão desafiará agravo por instrumento conforme o $\S 5^{\circ}$ do art. 356, CPC/15, preservando o andamento regular do processo na instância de origem. [...] Como sói, o cabimento do agravo não determina a natureza da decisão, decorrendo de uma opção legislativa para garantir a permanência dos autos na instância de origem, uma vez que não temos uma apelação incidental, por instrumento, como seria o adequado à espécie. Nem por isso o recurso cabível se submete ao regime do agravo, posto que seja a forma eleita pelo legislador". 32 Vale notar que há sérias objeções à legitimidade da aplicação da "teoria da causa madura", principalmente relacionadas à supressão de instância e à garantia fundamental de efetivo contraditório, inclusive com os desdobramentos de procedimento genuinamente dialógico. Neste sentido, Costa e Vasconcelos (2019, p. 180): “A aplicabilidade da teoria da causa madura fortalece o protagonismo judicial, inviabiliza a formação participada do mérito processual, ocasiona o cerceamento de defesa e consequentemente compromete a legitimidade democrática do provimento final de mérito. Tal afirmação se justifica inicialmente porque o contraditório, visto como princípio 
princípio da isonomia determina que se estenda essa possibilidade também aos agravos de instrumento interpostos contra decisão que veicule julgamento antecipado parcial de mérito. ${ }^{33}$

\section{CONCLUSÃO}

Ao longo deste estudo, procurou-se demonstrar que dispositivos diversos do Código de Processo Civil de 2015, tomados de maneira isolada, implicam um tratamento sensivelmente díspar da sistemática recursal e de efetivação de sentenças de mérito e de decisões interlocutórias que veiculam julgamento antecipado parcial de mérito - o que ofende a garantia fundamental da isonomia.

Assim, é necessário que se resgate, ainda no nível abstrato, o tratamento equânime de partes que se encontrem em posições equivalentes (tendo tido pretensões de mérito julgadas por meio de decisão proferida em exercício de cognição exauriente), de maneira a conformar o procedimento da maneira mais em conformidade com a noção de devido processo legal, considerados seus corolários de efetivo contraditório e de ampla defesa, com os meios e recursos a ela inerente.

Em síntese final e apertada, parece que a leitura da legislação infraconstitucional sob as luzes do texto constitucional, em geral, considerado o princípio da isonomia, em particular, impõe, desde logo, que se aplique ao recurso de agravo de instrumento interposto contra decisão interlocutória que veicula julgamento antecipado de mérito procedimento genuinamente análogo ao do recurso de apelação.

\section{REFERÊNCIAS}

ARAÚJO, José Henrique Mouta. Do Julgamento antecipado parcial do mérito. In: RIBEIRO, Sérgio Luiz de Almeida; GOUVEIA FILHO, Roberto P. Campos; PANTALEÃO, Izael Cristina Pinheiro (et. al.; coord.). Novo código de processo civil comentado, tomo II. São Paulo: Lualri, 2017, p. 91 a 94.

ARAÚJO, José Henrique Mouta. A Resolução parcial de mérito nas causas envolvendo os entes públicos e a diminuição do tempo do processo. In: CARMO, Valter Moura do; MOLLICA, Rogerio; SILVA, Germano Campos Silva Campos. Processo Civil. Florianópolis: CONPEDI, 2019, p. 78 a 97. Disponível em:

http://conpedi.danilolr.info/publicacoes/no85g2cd/xrok0191/4ch875wDEbM3PnRZ.pdf. Acesso em 4 dez. 2020.

ANTUNES, Thiago Caversan. O Respeito ao devido processo legal como direito fundamental de primeira dimensão. In: PIEROBON, Flávio; ANTUNES, Thiago Caversan (org.). Direitos

constitucional regente da processualidade democrática é fundamento de validade e legitimidade das decisões judiciais no Estado Democrático de Direito".

${ }^{33}$ Neste sentido, Lemos (2016b, p. 114): "Se na impugnação da sentença cabe a teoria da causa madura, de igual forma, deve a na impugnação da decisão parcial de mérito - via agravo de instrumento - caber a utilização da teoria da causa madura. Obviamente, não caberia na hipótese do artigo 1.013, $\S 3^{\circ}$, I, por esta versar sobre decisão sem mérito, contudo nos demais incisos, plenamente passível de utilização no agravo de instrumento contra a decisão parcial de mérito". Da maneira semelhante, Oliveira (2017, p. 9), ao tratar do recurso interposto contra a decisão que veicula julgamento antecipado parcial do mérito, opina que, “[...] não obstante o art. 1.013 estar no capítulo destinado à apelação, ele contém regras gerais sobre o efeito devolutivo que se aplicam a todos os recursos que não tenham limitação de devolutividade nem restrição cognitiva. Por não haver qualquer limitação no efeito devolutivo do agravo de instrumento que implique restrição cognitiva ao tribunal, tal dispositivo é-lhe plenamente aplicável. Destaca-se particularmente a aplicação ao agravo de instrumento do $\S 3^{\circ}$ do art. 1.013 do CPC". 
humanos e contemporaneidade: estudos em homenagem aos 60 anos da comissão interamericana de direitos humanos. Londrina, PR: Thoth, 2020, p. 269 a 281.

BONAVIDES, Paulo. Curso de direito constitucional. 14 ed. São Paulo: Malheiros, 2004.

BONAVIDES, Paulo. Do Estado liberal ao estado social. 8 ed. São Paulo: Malheiros, 2007.

BUENO, Cassio Scarpinella. Manual de direito processual civil [livro eletrônico]. 2 ed. São Paulo: Saraiva, 2016.

BUENO, Cassio Scarpinella. Novo código de processo civil anotado [livro eletrônico]. 3 ed. São Paulo: Saraiva, 2017.

CÂMARA, Alexandre Freitas. O Novo processo civil brasileiro. 3 ed. São Paulo: Atlas, 2017.

CARNEVALI, Orlando Augusto. Resolução parcial e progressiva de mérito: fracionamento em busca da brevidade e efetividade. In: DIDIER JR., Fredie (coord.). Novo CPC doutrina selecionada, vol. 2: procedimento comum. Salvador: Juspodivm, 2016, p. 367 a 402.

COSTA, Fabrício Veiga; VASCONCELOS, Lincoln Machado Alves de. A Problemática do contraditório e da decisão surpresa na aplicação da teoria da causa madura. In: Revista de Estudos Jurídicos UNESP, a. 23, n. 37, 2019, p. 153 a 184. Disponível em: https://periodicos.franca.unesp.br/index.php/estudosjuridicosunesp/article/view/2859. Acesso em 4 dez. 2020.

DELFINO, Lúcio. Código de processo civil comentado, vol. 1: arts. $1^{\text {o a }} 69$. Belo Horizonte: Fórum, 2020.

DIDIER JR., Fredie. Curso de direito processual civil, vol. 1: introdução ao direito processual civil, parte geral e processo de conhecimento. 19 ed. Salvador: Jus Podivm, 2017.

DONIZETTI, Elpídio. Curso didático de direito processual civil. 20 ed. São Paulo: Atlas, 2017a.

DONIZETTI, Elpídio. Novo código de processo civil comentado. 2 ed. São Paulo: Atlas, 2017 b.

LEMOS, Vinícius Silva. O Agravo de instrumento contra decisão parcial de mérito. In: Revista de Processo, vol. 259, set. 2016a. Disponível em:

http://www.mpsp.mp.br/portal/page/portal/documentacao_e_divulgacao/doc_biblioteca/bibli_ser vicos_produtos/bibli_boletim/bibli_bol_2006/RPro_n.259.12.PDF. Acesso em 4 dez. 2020.

LEMOS, Vinícius Silva. O Agravo de instrumento no novo cpc. São Paulo: Lualri, 2016b.

LUCON, Paulo Henrique Santos. Art. 357. In: TUCCI, José Rogério Cruz e; FERREIRA FILHO, Manoel Caetano; APRIGLIANO, Ricardo de Carvalho (et. al.; coord.). Código de processo civil anotado. São Paulo: AASP, 2015, p. 590 a 592.

MARINONI, Luiz Guilherme; ARENHART, Sérgio Cruz; MITIDIERO, Daniel. Novo curso de processo civil, vol. 2: tutela dos direitos mediante procedimento comum. São Paulo: Revista dos Tribunais, 2017. 
MARINONI, Luiz Guilherme; ARENHART, Sérgio Cruz; MITIDIERO, Daniel. Novo código de processo civil comentado [livro eletrônico]. 3 ed. São Paulo: Revista dos Tribunais, $2017 \mathrm{~b}$.

MEDEIROS NETO, Elias Marques de. O Recente ato conjunto n. 3/2020: TST. CSJT. CGJT e novamente - o debate sobre os efeitos do agravo de instrumento a ser interposto contra a decisão parcial de mérito de que trata o artigo 356 do CPC/15. 2020. Disponível em:

https://migalhas.uol.com.br/coluna/cpc-na-pratica/332205/o-recente-ato-conjunto-n--3-2020--tst--csjt--cgjt-e---novamente---o-debate-sobre-os-efeitos-do-agravo-de-instrumento-a-serinterposto-contra-a-decisao-parcial-de-merito-de-que-trata-o-artigo-356-do-cpc-15. Acesso em 4 dez. 2020.

MEDINA, José Miguel Garcia. Novo código de processo civil comentado: com remissões e notas comparativas ao cpc/1973 [livro eletrônico]. São Paulo: Revista dos Tribunais, 2015.

MEDINA, José Miguel Garcia. Curso de direito processual civil moderno [livro eletrônico]. 3 ed. São Paulo: Revista dos Tribunais, 2017.

MELLO, Celso Antônio Bandeira de. O Conteúdo jurídico do princípio da igualdade. 3 ed. São Paulo: Malheiros, 2010.

MONTENEGRO FILHO, Misael. Novo código de processo civil: modificações substanciais. São Paulo: Atlas, 2015.

NERY JUNIOR, Nelson. Princípios do processo na constituição federal. 10 ed. São Paulo: Revista dos Tribunais, 2010.

NEVES, Daniel Amorim Assumpção. Novo código de processo civil. Rio de Janeiro: Forense, 2015.

OLIVEIRA, Pedro Miranda de. O Regime especial do agravo de instrumento contra decisão parcial (com ou sem resolução do mérito). In: Revista de Processo, vol. 264, fev. 2017.

OLIVEIRA NETO, Olavo de; OLIVEIRA, Patrícia Elias Cozzolino de. Princípio da isonomia. In: OLIVEIRA NETO, Olavo; LOPES, Maria Elizabeth de Castro (org.). Princípios processuais civis na constituição. 2 tir. Rio de Janeiro, Elsevier, 2008, p. 137 a 153.

OTÁVIO NEGO, Deocleciano; PEREIRA, Mateus Costa; ALVES, Pedro Spíndola Bezerra. Do Julgamento antecipado parcial do mérito: primeira abordagem do tema no novo cpc. In: DIDIER JR., Fredie (coord.). Novo CPC doutrina selecionada, vol. 2: procedimento comum. Salvador: Juspodivm, 2016, p. 355 a 366.

PAULA, Alexandre Sturion de. Princípio da isonomia processual. In: RUZON, Bruno Ponich (org.). Princípios do processo civil brasileiro. Porto Alegre: Verbo Jurídico, 2013, p. 85 a 112.

SILVA, José Afonso da. Curso de direito constitucional positivo. 17 ed. São Paulo: Malheiros, 2000 .

SIQUEIRA, Thiago Ferreira. O Julgamento antecipado parcial do mérito no novo código de processo civil brasileiro. In: DIDIER JR., Fredie (coord.). Novo CPC doutrina selecionada, vol. 2: procedimento comum. Salvador: Juspodivm, 2016, p. 403 a 444. 
THEODORO JÚNIOR, Humberto. Curso de direito processual civil, vol. I: teoria geral do direito processual civil, processo de conhecimento e procedimento comum. 58 ed. Rio de Janeiro: Forense, 2017a.

THEODORO JÚNIOR, Humberto. Curso de direito processual civil, vol. III. 50 ed. Rio de Janeiro: Forense, 2017b. 